resembles $H$. rubida, Ricardo, in the antennæ. Bigot seems to have overlooked the second joint, which is very small, and described the third joint as the second one ; the first joint is long, cylindrical, and the third joint very wide, the basal division being large and swollen, the remaining divisions very small. The abdomen is black, with the segmentations grey; the two rows of spots mentioned by Bigot are hardly noticeable. The legs have two rings of light colour on the middle and posterior tibiæ, and the base of the fore tibiæ is yellowish. The wings have two indistinct rosettes.

VIII.-New Eastern Lepidoptera. By Colonel C. Swinhoe, M.A., F.L.S., \&c.

\title{
Family Satyridæ.
}

Genus Lyela, nov.

Fore wing triangular; costa arched, apex somewhat rounded, hinder angle much rounded, lower margin straight: hind wing with the costa and outer margin evenly curved; venation of both wings as in typical Cœnonympha. Palpi very hairy, third joint long, with the long hairs of the other joints extending beyond the tips; antennæ slender, about half the length of the costa, the club large, oval, spatulate, and very flat. No secondary sexual characters.

Type L. macmahoni, nov.

Erebia myops, Staud., belongs to this genus and has similar antennæ and shape. Dr. T. A. Chapman, in his "Review of the Genus Erebia," based on the examination of the male appendages, in Trans. Ent. Soc. 1898, p. 233, states that he places myops by itself.

\section{Lyela mucmahoni, nov.}

o f . Palpi blackish brown above, white beneath; antennæ above black, with broad white rings, below white, with narrow black rings, the club white beneath; head and body black above and below; eyes black, white beneath, with a white spot behind; legs blackish brown above, greyish ochreous white beneath. Wings of a uniform blackish brown, nearly black in some males, always darker below than above: fore wings with a large, blackish, subapical, round spot, with a broad dull orange ring round it; in two examples (a male 
and a female) there is a minute white dot within the black spot, on the right wing only. The female is like the male, but the wings are slightly longer, and therefore comparatively rather narrower, and the colour above and below is uniformly paler.

Expanse of wings $1 \frac{6}{10}$ inch.

Quetta, Beluchistan; several examples of both sexes, sent to me by Col. Sir A. H. McMahon.

\section{Family Nymphalidæ.}

\section{Cyrestis subobscurus, nov.}

ठ. Antennæ black; palpi with first joint white, second and third black above, white beneath; body and wings purplish blackish brown; the ground-colour of the wings in most parts is really purplish grey, but there are ten dark purplish-brown transverse bands across both wings, packed so closely together as to give the wings a blackish appearance : on the fore wings there is a white band between the fifth and sixth dark bands, a large white spot with square upper and lower ends in the middle of the next band, a small white dot above it near the costa, and an orange semi-square spot with a black dot in it at the hinder angle, and some thin white transverse streaks before the outer margin: on the hind wings most of the narrow spaces between the dark bands are more or less white, the whitest being in the middle, the first inner space next to it, one near the abdominal margin, a short streak below the apex, and another very thin one submarginal ; the anal lobe and space above it has a large orange patch, rounded on its upper side, with three or four black spots in it. On the underside the wings are very similarly marked, but the bands are dark and white alternately, the dark bands thin and much paler than they are above; body and legs white.

Expanse of wings $2 \frac{1}{10}$ inches.

Sitoli, Nias ; one example.

Allied to C. manalis, Erichson, and C. seminigra, GroseSmith : it is not referred to by Dr. Ludwig Martin in his monograph of the genus ('Iris,' 1903, p. 71); it belongs to his No. 2 Nivea-Gruppe Sykophages.

\section{Family Sphingidæ.}

\section{Genus Pentateucha, nov.}

* Proboscis fully developed; palpi upturned, slender, * I owe this diagnosis to Sir George Hampson. 
reaching about middle of frons, the second joint fringed with long hair in front, the third short; frons with tuft of hair ; antennæ of female ciliated; thorax clothed with long spatulate hair ; tibiæ fringed with long hair, the hind tibiæ with two pairs of spurs, the fore tarsi with three large curved claws on first joint; abdomen clothed with long rough hair ; frenulum present. Fore wing with the apex rounded, the outer margin evenly curved, crenulate; vein 3 from well before angle of cell; 5 from middle of discocellulars ; 6 from upper angle; 7, 8, and 9 stalked; 10 and 11 from cell : hind wing with vein 3 from well before angle of cell ; 5 from well above angle; 6 and 7 from upper angle ; 8 approximated to 7 beyond the cell.

\section{Pentateucha curiosa, nov.}

9 . Head and thorax clothed with deep red-brown hair tipped with white; pectus and legs rufous, the tarsi blackish; abdomen blackish mixed with grey-white, forming obscure segmental bands, the anal tuft and ventral surface rufous: fore wing clothed with dark red-brown hairy scales mixed with white; some rufous at base of inner area ; faint traces of a dark antemedial line, an oblique, elliptical, white discoidal spot; postmedial line with oblique dark bar from costa, then very indistinct, recurved to vein 3 , then incurved; subterminal line indistinct, double, oblique, waved, bent inwards to costa, where there is a white mark on it, a dentate line beyond it arising from apex, white and prominent to vein 6 , then indistinct and forming white points on the veins; cilia rufous, with whitish points at the veins: hind wing bright rufous, the inner area whitish, cilia with some white scales at tips. Underside of both wings rufous ; fore wing with indistinct pale discoidal spot, an obliquely curved postmedial band and prominent dentate white band from apex to above vein 6 : hind wing suffused with white to beyond middle; an oblique, slightly waved, medial rufous line and indistinct postmedial line, bent outwards to just above the anal angle, the terminal area irrorated with whitish.

Expanse of wings 4 inches.

Khasia Hills; one example of this very curious Sphinx.

\section{Family Syntomidæ.}

Syntomis aurea, nov.

๙ $q$. Antennæ black; head, thorax, and abdomen golden orange; a small black patch immediately behind the base of 
the antennæ; a transverse black line behind the neck, three longitudinal black lines running down from it on the thorax; abdomen with five thin segmental black bands, the extremity shot with metallic green. Wings hyaline, with the veins black : fore wings with the base yellow, the costal line black, the space between the costal line and subcostal vein yellow, and the basal half of the hinder margin smeared with dull yellow, and some yellow irrorations here and there on all the veins; a black bar across the interno-median interspace a little before the middle, a thin black band on the outer margin, thickened into a square spot on the extremities of veins 2 and 3 , and expanding at the apex, the space between veins 5 and 6 filled up with black, though in some specimens this band does not quite extend to the outer margin: hind wings with some yellow at the base and along the abdominal margin; the costa and outer margins with a thin black band, expanding into a spot below vein 2 , but not at the apex: legs black, tarsi with the upper half whitish.

Expanse of wings, ơ $1 \frac{3}{10}$, \& $1 \frac{5}{10}$ inch.

Khasia Hills; many examples of both sexes.

There are two examples in the B. M. from the Khasia Hills with S. fervida, Walker, from Moulmein, but it is not fervida; that species has no black bar in the interno-median interspace of the fore wings and the space between veins 5 and 6 is quite clear, and there are many other differences. I have before me seventeen examples, and all of them are constant in the characters given above.

\section{Family Deilemeridæ.}

\section{Deilemera formosana, nov.}

๙. Antennæ black; head and body above and below yellow ; palpi with the second and third joints black, tips of the former yellow; a large black spot on the frons, one on the top of the head, a pair on the collar and another pair behind them, a spot on the hind part of thorax; abdomen with paired dorsal and lateral black spots on each segment: fore wings brownish mouse-colour; a wedge-shaped white streak from the base; a large white discal patch which nearly touches the costa, expands downwards, has dentated sides, is joined in the middle to the outer margin by a band with a large brown spot in it, and a small one on the margin, is rounded below the median vein, has a tooth on the inner side, with a large brown spot in it, opposite the basal wedgeshaped streak; a white subapical spot: hind wings white, with a broken mouse-coloured marginal border. 
Expanse of wings $1 \frac{9}{10}$ inch.

Formosa ; one example.

Veins 6 and 7 of the hind wings on a short stalk, palpi long, antennæ with long pectinations; hind wings as in D. carissima, Swinh., with an excavation before the anal angle, which is produced. Belongs to Section II. of my monograph of the genus (Trans. Ent. Soc. 1903, p. 53).

\section{Family Zygænidæ.}

\section{Isbarta padanga, nov.}

ơ ‥ Palpi white, last joint black; antennæ, head, body, and wings black; two white spots behind the head, two on the thorax in front, white dorsal and lateral spots on each segment of the abdomen, and white bands beneath : fore wing with a white basal spot, all the markings white; a thin streak on the basal half immediately below the costal line, a short thin streak immediately below this not reaching the base; a streak on the subcostal vein, extending from the middle to the end of the cell, thickened in its centre; an oval spot at the lower end of the cell, continued a short distance in a fine line on the vein inwards; two thick streaks below the cell from near the base to the middle, a thinner streak on the hinder margin from near the base for three fourths its length; an oval spot beyond the end of the cell, two above it in a triangular shape, two in the disk a little below and outside, a longer spot below and a little inwards, and another similar spot below this towards the hinder margin not far from the angle; a submarginal row of spots rather close to the margin, but curving inwards below the apex : hind wings with streaks on the cell-veins, reaching the base, the upper one not reaching the end of the cell; a curved row of discal elongated spots, a submarginal row of seven smaller spots; three streaks below the cell, extending from the base and running into the submarginal spots; a broader streak on the abdominal margin. On the underside the markings on the wings are as above, but the streaks are broader and the spots larger; thorax spotted with white; legs streaked with white.

Expanse of wings, ơ $2 \frac{9}{10}$, $\& 3 \frac{1}{10}$ inches.

Padang, Sumatra; one pair.

\section{Pompelon affinis, nov.}

§. Frons white, with pale blue reflections; antennæ black; head, body, and wings dark blackish brown; a crimson line behind the head; abdomen with the anal tuft 
and underside crimson, with lateral black spots on each segment: fore wings above with dull pale purplish reflections on the costa and outer veins, the costal reflections expanding somewhat towards the apex: hind wings with similar reflections on the apical portions. Underside dull brown; fore wings with a large dull ochreous spot at the upper end of the cell; blue reflections on the costa, subcostal vein, the veinlet within the cell, and on all the outer veins; hind wings without any reflections; the brown colour on all the wings pale towards the outer margins ; pectus and thorax crimson; legs black.

Expanse of wings $2 \frac{7}{10}$ inches.

Padang, Sumatra; one example.

Nearest to $P$. amplicatum, Butler, from the Celebes; differs in the nature of the reflections above and is very different beneath.

\section{Family Lymantriidæ.}

\section{Dasychiva albiplaga, nov.}

$\delta$. . Antennæ with the shafts whitish, pectinations greyish brown; palpi brown above, greyish white beneath; head and fore part of thorax greyish white; thorax greyish brown; abdomen greyish white: fore wing greyish brown, smeared in parts with whitish, more prominently so in the female; a broad, almost straight, whitish stripe from the base to the apex, through the upper part of the wing, more or less obsolescent in one of the females; an antemedial dentated whitish line, lined with brown on its outer side; a postmedial, dentated, and recurved similar line, lined with brown on its inner side, curving inwards above the hinder margin close to the antemedial line; a submarginal lunular whitish thin band, which also curves inwards above the hinder margin; a marginal row of brown lunules, margined on each side with whitish ; cilia white, with brown patches; most of these lines are almost invisible in the male, but quite distinct in the female: hind wings pale brown in the male, almost white in the female : body, legs, and wings grey ; a discal, nearly straight, grey, thin band across the fore wing and indicated on the upper portion of the hind wing.

Expanse of wings, of $1 \frac{1}{10}$, $+1 \frac{7}{10}$ inch.

East Java; one male and five females.

In Ann. \& Mag. Nat. Hist. (7) xviii. p. 405 (1906), I described this female erroneously as the female of Orgyia nebulosa, Walker, with which I originally received it; the Ann. \& Mag. N. Hist. Ser. 8. Vol. i. 
venation being almost identical, I thought it must be the female of that species, but a closer examination with the Dasychira male now received with a female showing similar markings leaves no doubt of my error.

\section{Family Quadrifidæ.}

\section{Nyctipao superba, nov.}

9. Blackish brown, the outer half the darkest and nearly pure black, the ocellus broader than in caprimulgus, Fabr., the dull orange ring tinged with blue, and with.pale bluewhite markings as in jaintiana, Swinh.; a discal pure white complete band across both wings, not quite touching either costa or abdominal margin, sinuous throughout, with two blunt outward projections before and above the middle on the fore wings, and commencing with two almost square spots below the costa on the hind wings. On the underside the wings are paler, especially towards the base and hinder margin of fore wings, where it has a red tinge; the white band as above, except that on the fore wings it commences with three lunular blunt spots below the costa; cilia of both wings black: body above and below blackish brown; antennæ, palpi, breast, and legs black.

Expanse of wings $4 \frac{1}{10}$ inches.

Khasia Hills; one example.

A very handsome insect.

\section{Family Geometridæ.}

\section{Thalassodes viridifascia, nov.}

o ㅇ. Palpi above and antennæ ochreous; palpi below, head, body, and wings above and below white; thorax mostly green, and green dorsal bands on the abdomen. Wings thinly clothed, sparsely striated with green: fore wing with the costal line ochreous, the base green; two straight, slightly oblique, broad green bands, ante- and postmedial, neither quite reaching the costa; apex green, this colour narrowing down the outer margin: hind wings with a broad, straight, medial green band in continuation of the antemedial band of the fore wings ; some green on the outer and abdominal margins; marginal lines of both wings dark; cilia white, with a pale green inner band. Underside whitish, without markings ; legs ochreous.

Expanse of wings 2 inches.

N. Borneo ; one pair. 
Belongs to the group of which orthdesma, Lower *, from Queensland, albifusa, Warren, from Fergusson Island, and nivestrota, Warren, from N. Guinea, are examples.

\section{Dysphania fannitta, nov.}

$\delta$ f. Yellow, of the colour of militaris, Linn. ; palpi black at the sides, tips yellow, last joint black; antennæ black, a black stripe down the middle of the frons, a black stripe between the antennæ, one on the neck, one on the shoulders, and one before the middle; the abdomen above and below pure yellow, without any markings, except for a black stripe at the base above corresponding to the black stripe across the base of the hind wing, which runs up into the fore wing, expands on the interno-median interspace, is there excavated on its outer side, then is bent straight inwards on to the costa at one fourth from the base ; costal line black; a thick streak from the base on the median vein, coming to a point on the bent band; outer third of the wing black, with discal and subapical bands of nearly white semihyaline square spots, the spot above vein 3 being long and narrow; the yellow space between the outer black portion and the inner bent band limited to four large yellow spots divided by the veins : the hind wings are marked much as in subrepleta, Walker, but the outer veins are thickly streaked with black and the outer margin has a lunular black line; the hind wings are more ample than usual and project a little between veins 3 and 4 .

Expanse of wings $3 \frac{2}{10}$ inches.

Nias; one male and two females.

\section{Dysphania jessica, nov.}

$\delta$. . Of the same yellow colour as militaris, Linn., but smaller, uniformly not larger than subrepleta, Walker, = bellonaria, Guen. ; markings somewhat similar to the former, but the black subbasal band outside the basal spots is continuous and bent round, being very slightly angled outwardly on the median vein, and there is an elongated spot with square sides on vein 1 attached to the outside of the band which is reduced to a small spot usually in the female; the black basal stripes are broken, and not even and regular as in militaris; in the hind wing the discal black transverse band is continuous.

Expanse of wings $31_{10}^{2}$ inches.

* Tr. Roy. Soc. S. Austral. 1894, p. 86; Nov. Zool, iii. p. 293, and x. p. 365 . 
Nancoury, Nicobars; three males and two males (type).

Pt. Blair, Andamans; one male and two females.

Bassein, Burma ; one female.

There are a good many examples from the Nicobars and Andamans in the B. M., and all that I have seen are perfectly constant in the above-mentioned characters.

\section{Pareumelea rostrata, nov.}

o $q$. Antennæ, body, and wings dark ochreous olive; the apex of fore wings broadly and the outer margins of both wings more narrowly clear ochreous yellow; the olive colour thickly striated with dark brown, and a band of this colour extends below the apex of fore wings nearly to the outer margin, then the yellow marginal band narrows downwards, but on the hind wings it is fairly uniform in width and is somewhat angled in the middle, as in P. hortensiata, Guen. On the underside the wings are olive-brown without striations, the band as above; body and legs yellow.

Expanse of wings $2 \frac{5}{10}$ inches.

Menado, Celebes; one pair.

It lacks the upper discal large yellow spot of hortensiata and the yellow marginal band is of a different formation.

\section{IX.-Two new Mammals from Asia Minor. By Gerrit S. Miller.}

The British Museum contains specimens of a shrew and dormouse from Asia Minor, neither of which appears to have been hitherto described.

\section{Neomys teres, sp. n.}

1906. Neomys fodiens, Thomas, P. Z. S. 1905, ii. p. 522 (April 1906).

Type.-Adult male (skin and skull). B.M. no. 5. 10.4.17. Collected at edge of brook in mountains (altitude 7000 feet) 25 miles north of Erzeroum, Turkey in Asia, July 8, 1905, by R. B. Woosnam. Presented by Col. A. C. Bailward. Original number 53.

Diagnosis.-Similar to Neomys anomalus, Cabrera *, and

* Ann. \& Mag. Nat. Hist. ser. 7, xx. p. 214 (September, 1907). San Martin de la Vega, Province of Madrid, Spain. 


\section{$2 \mathrm{BHL}$ Biodiversity Heritage Library}

1908. "New Eastern Lepidoptera." The Annals and magazine of natural history; zoology, botany, and geology 1, 60-68.

https://doi.org/10.1080/00222930808692357.

View This Item Online: https://www.biodiversitylibrary.org/item/78381

DOI: https://doi.org/10.1080/00222930808692357

Permalink: https://www.biodiversitylibrary.org/partpdf/61884

\section{Holding Institution}

University of Toronto - Gerstein Science Information Centre

\section{Sponsored by}

University of Toronto

\section{Copyright \& Reuse}

Copyright Status: NOT_IN_COPYRIGHT

This document was created from content at the Biodiversity Heritage Library, the world's largest open access digital library for biodiversity literature and archives. Visit BHL at https://www.biodiversitylibrary.org. 